\title{
Problemy Z ARGUMENTACJĄ ZWOLENNiKóW Nowoczesnej TeOriI PieniężneJ PRZECIW DOCHODOWI PODSTAWOWEMU: KOMENTARZ DO TEUMACZENIA
}

\author{
MACIEJ SZLINDER
}

Debaty między zwolennikami bezwarunkowego dochodu podstawowego (BDP) i gwarancji zatrudnienia (GZ) zbyt często przypominają dialog głuchych. W bezpośrednich dyskusjach jedni mówią o kwestiach etycznych i problemach systemów zabezpieczenia społecznego, a drudzy o skutkach makroekonomicznych ${ }^{1}$. Obie strony zbyt często wybierają sobie również przeciwników, z którymi łatwiej im polemizować. Guy Standing (2017) w przetłumaczonym w tym numerze rozdziale swojej książki odwołuje się do wysuwanego przez Nową Partię Pracy (z czasów Gordona Browna) programu nominalnie nazywającego się gwarancją zatrudnienia. Program ten jest jednak daleki od tego, co za GZ uznaliby kluczowi zwolennicy tej koncepcji. Z drugiej strony Pavlina Tcherneva w wygodny dla siebie sposób zakłada, że „,rdzeniem propozycji dochodu podstawowego jest to, że ma on być neutralny dla budżetu” (Tcherneva 2017, 133), choć jest to element zupełnie przygodny i niekonieczny. Zbyt często też przedstawiciele obu stron dowolnie dobierają wyłącznie słabsze elementy różnych, niespójnych

\footnotetext{
${ }^{1}$ Dobrym przykładem takiej „,wymiany opinii” jest numer Basic Income Studies 7(2), w którym Guy Standing i Pavlina Tcherneva pozornie pisząc o tym samym (porównanie BDP z GZ w kontekście prawa do pracy), piszą „obok siebie”. Brytyjski ekonomista opisuje głównie problemy związane z opresyjnością systemów workfare (do których zalicza GZ), stosowaniem kryterium dochodowego i testów behawioralnych, a także kwestie administracyjne. Skupia się zatem na zarzutach etycznych i praktycznych. Tcherneva zaś odpowiada koncentrując się na konsekwencjach makroekonomicznych (Standing 2013, Tcherneva 2013).
} 
teorii, nie skupiając się na jednej konkretnej propozycji, którą uznają za najmocniejszą i stawiającą największe wyzwania.

W tym komentarzu chciałbym zatem skupić się na konkretnej propozycji GZ ściśle powiązanej z założeniami Nowoczesnej Teorii Pieniężnej (NTP), a także wynikającej w niej krytyki BDP. Stanowisko to w syntetyczny i klarowny sposób przedstawia tłumaczony w tym numerze artykuł Pavliny Tchernevy. Przyznaję, że bliska jest mi perspektywa ekonomii heterodoksyjnej i podzielam znaczną część uwag krytycznych wyrażanych przez NTP względem założeń ekonomii neoklasycznej, jak np. krytykę wątpliwej koncepcji „stopy bezrobocia nie zwiększającej inflacji”" (Non-Accelerating Inflation Rate of Unemployment, NAIRU), na która powołuje się np. Guy Standing (2017). Jednak szczegółowe założenia i elementy tej teorii budzą szereg wattpliwości natury zarówno empirycznej, jak i politycznej.

Zanim przejdę do omówienia tych ostatnich, pozwolę sobie jeszcze zaznaczyć, że w tym krótkim tekście nie podejmuję kwestii ekologicznych opisywanych przez Tcherneva, co nie znaczy, że nie zasługują one na uwagę. Wręcz przeciwnie - niektóre wątpliwości wskazywane przez nią są również elementem refleksji i dyskusji w gronie zwolenników BDP².

\section{Podaż pracy i inflacja}

Głównym zarzutem Tchernevy względem BDP jest to, że jej zdaniem prowadzi on „do destabilizujących skutków względem cyklu koniunkturalnego, z uwagi na swoją proinflacyjność i negatywny wpływ na poziom partycypacji i produkcji” (137). Mamy tu więc do czynienia z połączeniem dwóch argumentów: 1) BDP spowoduje wyraźny spadek podaży pracy oraz 2) BDP wywoła spiralę inflacyjna (a prawdopodobnie hiperinflację). Rozpatrzmy te zarzuty po kolei.

Pierwszy argument wymaga oczywiście empirycznej weryfikacji, jednak dostępne dane i analizy wydają się czynić go pozbawionym podstaw. W istniejących systemach zabezpieczenia społecznego, szczególnie tych opartych na kryterium dochodowym, powszechnie występuje tzw. pułapka bezrobocia, czyli sytuacja, w której osoba nie pracująca podejmując zatrudnienie traci świadczenia, co czyni podjęcie pracy działaniem nieopłacalnym. Między innymi z uwagi na ten element wiele rządów europejskich interesuje się koncepcją BDP, który tej pułapki nie zawiera, ponieważ nie jest zależny ani od dochodu danej osoby, ani od jej statusu na rynku pracy. Ponadto ani programy pilotażowe BDP w krajach peryferyjnych (Davala 2015), ani eksperymenty innych rozwiązań usuwających pułapkę bezrobocia (jak negatywny podatek

\footnotetext{
${ }^{2}$ W tym kontekście warto szczególnie zwrócić uwagę na numer czasopisma Basic Income Studies 4(2)/2009 poświęcony tej tematyce (BIS 2009). Numer ten oraz zawarte w nim problemy zostały częściowo omówione i poddane analizie w pracach dostępnych również w języku polskim (Moll 2014, Szlinder 2016, Torrens 2016).
} 
dochodowy) w krajach centrum (Widerquist i Sheahan 2012, 20) nie wykazały tendencji do wycofywania się w kierunku bierności zawodowej czy znaczącego spadku podaży pracy.

Oczywiście należy się spodziewać, że część osób zatrudnionych na najgorzej płatnych, pozbawionych zabezpieczeń i uciążliwych miejscach pracy zdecyduje się je porzucić, co wymusi poprawę jakości zatrudnienia pod względem płac i warunków pracy (lub w niektórych przypadkach w razie możliwości technologicznych i opłacalności - automatyzację). Nie znaczy to jednak, że całkowita podaż pracy się zmniejszy, te same osoby (a także część osób do tej pory nieaktywnych zawodowo lub bezrobotnych) będa mogły znaleźć zatrudnienie w nowych miejscach pracy, powstałych w wyniku zwiększonej siły nabywczej społeczeństwa (wynikającej z redystrybucji od osób lepiej uposażonych, skłonnych w większym stopniu do oszczędzania, do osób gorzej sytuowanych bardziej skłonnych do konsumpcji). Dla niektórych osób BDP może stanowić też szansę na rozpoczęcie własnej działalności gospodarczej czy to indywidualnie czy też w ramach kooperatyw ${ }^{3}$.

Wskazany wyżej skutek w postaci podwyżki płac leży u źródła drugiego kluczowego argumentu Tchernevy, zgodnie z którym BDP jest ze swej natury rozwiąaniem inflacjogennym. Ekonomistka pisze:

W celu nakłonienia osób otrzymujących BDP do powrotu na rynek pracy niektórzy pracodawcy będą musieli zaproponować wyższe płace (co na pierwszy rzut oka wydaje się pożądanym efektem). Jednak wkrótce potem ci sami przedsiębiorcy podniosą ceny, aby zrekompensować sobie wzrost kosztów płacowych (135).

Aby utrzymać BDP na poziomie zapewniającym zaspokojenie podstawowych potrzeb konieczne będzie jego podwyższenie, co z kolei znów wymusi kolejną podwyżkę płac i cen, a w efekcie spiralę inflacyjną (lub wręcz hiperinflację) ${ }^{4}$.

Podstawowym problemem w tym rozumowaniu jest założenie, że każda podwyżka płac przekłada się bezpośrednio na proporcjonalną podwyżkę cen. Oznacza to, że za stała i niezmienną uznaje się relację między płacami a zyskami. Relacja ta jednak nie jest stała i ulega nieustannym zmianom w wyniku walk klasowych, prowadzonych zarówno bezpośrednio przez organizacje pracownicze, jak i pośrednio poprzez wpływanie na kształt instytucjonalny państw opiekuńczych ${ }^{5}$. Co więcej, założenie to jest nie tylko błędne empirycznie, ale także bardzo

\footnotetext{
${ }^{3}$ Keynesowski ekonomista William A. Jackson zwraca uwagę na jeszcze jeden argument przekonujący do zwiększenia podaży pracy w wyniku wprowadzenia dochodu podstawowego - zmniejszenie godzin pracy. Jego zdaniem ludzie ,nie postrzegaliby już pracy na pełny etat jako jedynego źródła dochodu i mieliby większą swobodę wyboru rodzaju i zakresu podejmowanej pracy”, a dochód podstawowy „mógłby zachęcić do pracowania mniejszej liczby godzin i, tym samym, zwolnić czas pracy na rzecz bezrobotnych" (Jackson 1999, 652).

4 Argument o „pułapce inflacyjnej” powtarzają również Bartosz Mika i Mariusz Baranowski w artykule znajdującym się w tym numerze Praktyki Teoretycznej (Baranowski, Mika 2017). Zob. także Tcherneva 2006.

${ }^{5}$ Engelbert Stockhammer jako główne przyczyny spadku udziału płac w PKB od lat osiemdziesiątych XX wieku w krajach OECD wskazuje procesy finansjalizacji, globalizacji i demontaż państw dobrobytu (wraz z osłabieniem związków zawodowych) (Stockhammer 2012).
} 
niepokojące pod względem politycznym. Zgodnie z nim nie jest bowiem możliwe zmniejszenie poziomu wyzysku, a każda walka o podwyżkę płac jest de facto daremna ${ }^{6}$. Takie stanowisko uderza choćby w sens działań wielu związków zawodowych i organizacji lewicowych.

BDP bez wątpienia wzmocni pozycję przetargowa pracowników i w związku z tym przełoży się nie tylko na wzrost płac nominalnych i realnych, ale również płac względnych, tzn. wzrost udziału płac i spadek udziału zysków w PKB (zob. Szlinder 2013, Manjarin i Szlinder 2016). Tym samym wzrost cen będzie wyraźnie niższy niż wzrost płac, a tym samym „spirala” inflacyjna będzie miała charakter wygaszający.

Co ciekawe, poczattkowy skok inflacyjny Tcherneva przewiduje również w odniesieniu do efektów programu GZ. Przyczyna, dla której nie uważa, że byłby to problem, jest brak indeksacji płac w ramach tego programu (Tcherneva 2013, 73). Oznacza to jednak, że jeśli płaca w programie GZ zostanie ustalona na poziomie płacy minimalnej, to po wzroście cen, nie będąc dostosowywana do inflacji, jej realna wartość spadnie poniżej tego poziomu.

\section{Kotwica dla cen?}

Tcherneva podaje jeszcze drugi powód dlaczego BDP będzie prowadził do inflacji. Jak pisze:

Jeśli wprowadza się program, przez który populacja może swobodnie otrzymywać jednostkę, która realizuje zobowiązanie podatkowe, wartość waluty drastycznie spadnie. Chociaż nie musi się to zdarzyć od razu, z czasem wartość bezwarunkowo zapewnianej waluty ostatecznie będzie dążyć do zera. Należy podkreślić, że dochód podstawowy nie wywołuje inflacji, ponieważ jest finansowany z „fiducjarnego” pieniądza, ale ponieważ waluta jest z istoty „darmowa” (...) i jest dostarczana wszystkim na życzenie. Tym samym efektywnie unieważnia cel podatków - stworzenie popytu na rządową walutę. (133)

Jednak mamy tutaj do czynienia z pewnym nieporozumieniem, ponieważ w wypadku BDP waluta nie jest wcale dostarczana „na życzenie”. W ramach tego rozwiązania postuluje się regularne otrzymywanie jedynie pewnej określonej ilości pieniędzy. Nie można zatem mieć tyle waluty, ile się chce bez wysiłku (wówczas faktycznie jej wartość dążyłaby do zera).

Zgodnie z NPT „,[s]iłę nabywczą mierzy się za pomocą jednostek pracy, które może kupić waluta" (137) a rolę kotwicy antyinflacyjnej pełni program gwarancji zatrudnienia. Problem w tym, że te jednostki pracy są zupełnie niemiarodajne. W przeciwieństwie np. do społecznie niezbędnego czasu pracy stanowiącego wartość towarów w Marksowskiej teorii

\footnotetext{
${ }^{6}$ Co ciekawe, w tę pułapkę wpadł również Eduardo Garzón, ekonomista związany ze Zjednoczoną Lewicą (Izquierda Unida) i czołowy hiszpański zwolennik GZ, który również użył tego argumentu w artykule dyskutującym z autorami hiszpańskiego modelu finansowania BDP Jordim Arcaronsem, Danielem Raventósem i Lluísem Torrensem (Garzón 2014).
} 
wartości opartej na pracy, nie mamy tutaj do czynienia z żadnym mechanizmem pozwalającym porównać godzinę czasu pracy w ramach jednego gwarantowanego miejsca pracy z druga godziną w ramach tego programu. Jest tak, ponieważ w promowanej przez zwolenników NTP wersji GZ prace mają być co prawda użyteczne, ale ich efekty nie mogą być sprzedawane i nie moga konkurować z sektorem prywatnym ani tradycyjnym sektorem publicznym (Tcherneva 2003, 4; Mitchell i Watts 2005, 75; Kaboub 2013, 62; Murray 2013, 112, 117; Wray 2013 170, 174)7. Skoro, jak pisze Tcherneva, wartość waluty jest przy GZ „zakotwiczona przez wysiłek wydatkowany, aby zarobić ten dochód”, to musi istnieć jakiś mechanizm mierzenia i standaryzowania tego „wysiłku”. Jeżeli efekty pracy nie mogą być sprawdzane za pomoca porównania ich na rynku, to konieczny wydaje się jakiś niezwykle efektywny aparat dyscyplinarny pozwalający uzyskiwać równe dawki „wysiłku” w godzinie pracy gwarantowanej. Bez niego waluta nie może być w żaden sposób „zakotwiczona”, ponieważ ten sam dochód, tę samą ilość waluty, można uzyskać skrajnie różnym „wysiłkiem”.

W tym miejscu warto zadać jeszcze jedno ważne pytanie: jaka jest różnica w odniesieniu do stabilizowania waluty między wykonywaniem jakiejś pracy (uczeniem dzieci angielskiego, opieką nad starszym sąsiadem czy dbaniem o społeczny ogród) w ramach stworzonego w programie GZ miejsca pracy a wykonywaniem tej samej pracy, dzięki czasowi i bezpieczeństwu zapewnianemu przez BDP? Ponieważ trudno utrzymywać, że istnieje jakaś sensowna próba wskazania takiej różnicy, należy uznać, że zwolennicy NTP nie wierza po prostu, że ludzie sami z siebie będą angażować się w społecznie pożyteczną aktywność, jeśli nie będzie to warunkiem uzyskania przez nich środków utrzymania. Przyjmuja zatem pewne antropologiczne założenie o dość konserwatywnym charakterze, głoszące, że bez bezpośredniej korzyści materialnej lub przymusu ekonomicznego ludzie nie są skłonni do prospołecznej aktywności.

\section{Przykłady empiryczne i próby połączenia}

Ani BDP ani GZ nie zostały tak naprawdę sprawdzone w praktyce przez żadne państwo ${ }^{8}$. Tcherneva odwołuje się jednak do ograniczonego programu GZ - argentyńskiego programu bezpośredniego tworzenia miejsc pracy dla głów rodzin (Programa de Jefes y Jefas de Hogar Desocupados, PJJHD). Niezwykle pozytywny opis przebiegu i wyników tego programu wydaje

\footnotetext{
${ }^{7}$ Co ma oczywiście sens, ponieważ gdyby efekty prac w ramach GZ konkurowały z miejscami pracy spoza tego programu, to przy stałej, niskiej i jednolitej płacy w ramach GZ efektem byłoby wypieranie lepiej płatnych miejsc pracy niż płaca w GZ przez miejsca pracy w ramach GZ i ogólna obniżkę płac.

${ }^{8}$ Oczywiście prowadzone były np. eksperymenty z BDP w Indiach, a obecnie trwa eksperyment w Finlandii. Ten drugi jednak nie spełnia wielu cech definicyjnych BDP i jest eksperymentem z bezwarunkowym niepowszechnym świadczeniem niepodstawowym. Co jednak ważniejsze, eksperymenty nie są w stanie przynieść nam wiedzy na temat efektów makroekonomicznych, gdyż ich skala jest zbyt mała. Prawdziwym „eksperymentem” dla któregokolwiek z tych rozwiązań będzie dopiero wprowadzenie tego rozwiązania na poziomie jakiegoś państwa narodowego.
} 
się jednak dość jednostronny. Argentyńscy badacze w licznych publikacjach wskazywali na problemy związane $z$ tym programem: od znikomego wpływu na obniżenie bardzo wysokiego poziomu ubóstwa (Barbeito et al. 2007; Lo Vuolo 2004), przez tworzenie pułapek zniechęcających do poszukiwania zatrudnienia poza programem (Gasparini, Haimovich i Oliveri 2009), po sztuczne dzielenie gospodarstw domowych w celu zakwalifikowania się do programu (Lo Vuolo 2004). Rubén Lo Vuolo zwrócił również uwagę na to, że program w mniejszym stopniu objął rodziny żyjące w skrajnej biedzie w porównaniu z mniej ubogimi, co było prawdopodobnie efektem wykluczenia osób, które nie mogły podjąć pracy (np. części samotnych matek) oraz osób, które nie miały dzieci na swoim utrzymaniu (Lo Vuolo 2004, 7 8). Trzeba zaznaczyć, że w ramach tej ostatniej grupy znajdowały się osoby, które napotykaja największe problemy w znalezieniu płatnego zatrudnienia, tj. ludzie młodzi oraz osoby starsze, których dzieci nie należa już do ich gospodarstw domowych. Dla części badaczy PJJHD był przykładem polityki workfare (Lo Vuolo 2004, 7; Barbeito et al. 2007, 13), a zdaniem Barbeito et al. (2007, 13) głównym jego skutkiem było raczej zwiększenie kontroli społecznej niż poprawa dobrobytu ludzi.

Pod koniec artykułu Tcherneva sugeruje rozwiązanie „kompromisowe” między BDP a GZ, za które uważa koncepcję dochodu partycypacyjnego zaproponowaną przez angielskiego ekonomistę Anthony'ego Atkinsona (Atkinson 1995, 1996). Niestety jest to kompromis pozorny, na co wskazuje dokładniejsze przyjrzenie się tej koncepcji. Dokonali tego w swojej analizie aspektów administracyjnych dochodu partycypacyjnego Jurgen De Wispelaere i Lindsay Stirton, pokazując, że w zależności od sposobu zdefiniowania „partycypacji” mamy do czynienia z diametralnie różnymi rozwiązaniami (De Wispelaere i Stirton 2007). Jeśli zostanie ona zdefiniowana szeroko (co rzeczywiście odpowiadałoby postulatom poszerzenia zakresu pojęcia pracy przez zwolenników BDP), aby objąć wszelką użyteczną społecznie aktywność również sprawowaną we własnym domu czy sąsiedztwie, to powstaje pytanie o zakres kontroli takiej aktywności. Gdyby kontrola ta była traktowana poważnie, to generowałaby ogromne koszty administracyjne, a także wiązałaby się ze znacząca ingerencją państwowego aparatu kontroli w życie codzienne obywateli (stała obserwacja wraz z liczeniem czasu poświęconego deklarowanym aktywnościom). Jeśli zaś opierano by się wyłącznie na nie weryfikowanych deklaracjach, to mielibyśmy do czynienia z rozwiązaniem zbliżonym do BDP z wyłączeniem części osób najbardziej wykluczonych (nie wiedzących, jak składać deklaracje będące warunkiem otrzymania świadczenia) lub najbardziej uczciwych (nie chcących deklarować czegoś, czego nie wykonuja). Rozwiązaniem trzecim jest ścisłe ograniczenie aktywności kwalifikujących się jako „partycypacja” do tych aktywności, które łatwo i bez nadmiernych kosztów moga zostać zweryfikowane, czyli np. rejestrowana praca zarobkowa, studia na wyższej uczelni czy oficjalny wolontariat w uznanej organizacji pozarządowej. W ten sposób wykluczono by jednak znaczną ilość rzeczywiście użytecznych społecznie aktywności, 
które są trudne do nadzorowania, szczególnie tych związanych z pracą domową i nieformalną na rzecz wspólnoty. De Wispelaere i Stirton nazywają tę strategię mianem „miękkiego workfare” (De Wispelaere i Stirton 2007, 540, 542, 543) ${ }^{9}$. Dochód partycypacyjny jest więc immanentnie niestabilny i musi osunąć się $w$ jedną $z$ trzech wersji: ułomnego BDP, koszmaru biurokratycznego nadzoru lub słabej wersji workfare. Żadna z tych wersji nie stanowi kompromisu między zwolennikami GZ i BDP (ci pierwsi na pewno nie zaakceptuja pierwszej $z$ tych wersji, a drudzy dwóch ostatnich).

\section{Podsumowanie}

Koncepcja Gwarancji Zatrudnienia, szeroko opisywana i promowana przez środowiska związane z Nowoczesną Teorią Pieniężną, wydaje się najbardziej kompleksową i interesująca wersją tego projektu. Niestety przedstawiana przez jej przedstawicielki i przedstawicieli krytyka Bezwarunkowego Dochodu Podstawowego odwołująca się do drastycznie zmniejszonej podaży pracy i inherentnej inflacyjności tego rozwiązania wydaje się być pozbawiona podstaw. Co więcej, założenia ekonomiczne i antropologiczne leżące u podłoża NPT i tworzonej w jej ramach koncepcji GZ (stałość stopy wyzysku; niezwiększane niskie płace w ramach GZ; założenie, że ludzie nie będą robić nic użytecznego bez bezpośrednich korzyści lub przymusu), a także wybiórcze przytaczanie danych nt. przykładów empirycznych skłaniają do spoglądania na nią z dużą dozą ostrożności i krytycyzmu, szczególnie z punktu widzenia środowisk lewicowych i postępowych.

\footnotetext{
${ }^{9} \mathrm{Na}$ tę wersję zdaje się wskazywać Atkinson w swojej odpowiedzi De Wispelaere i Stirtonowi zawartej w jego ostatniej książce Nierówności: Co da sie zrobiç? (Atkinson 2017, 363-365).
} 


\section{Wykaz literatury}

Atkinson, Anthony B. 1995. Public Economics in Action: The Basic Income/Flat Tax Proposal. Oxford: Clarendon Press, 1995.

Atkinson, Anthony B. 1996. „The Case for a Participation Income”. Political Quarterly 67 (1): $67-70$.

Atkinson, Anthony B. 2017. Nierówności: Co da sie zrobić? Tłum. Mikołaj Ratajczak, Maciej Szlinder. Warszawa: Wydawnictwo Naukowe PWN.

Baranowski, Mariusz i Bartosz Mika. 2017. „Wielokryterialna ocena projektów bezwarunkowego dochodu podstawowego i gwarantowanego zatrudnienia”. Praktyka Teoretyczna 2(24): 39-67.

Barbeito, A., et al. 2007. „Contribución para el debate de propuestas alternativas de política económica y social en Argentina - 2007”. Buenos Aires: Documentos deTrabajo / 59 CIEPP Centro Interdisciplinario para el estudio de las Políticas Públicas, http://www.ciepp.org.ar/index.php?page=shop.product_details\&flypage=flypage_new 1.tpl\&product_id=59\&category_id=8\&option=com_virtuemart\&Itemid $=2 \& l a n g=e s$ (dostęp 3 sierpnia 2017).

Basic Income Studies 4(2). 2009.

Davala, Sarath, Renana Jhabvala, Soumya Kapoor Mehta i Guy Standing. 2015. Basic Income: A Transformative Policy for India. London, New York: Bloomsbury Academic.

De Wispelaere, Jurgen i Lindsay Stirton, 2007. „The Public Administration Case against Participation Income", Social Service Review 81(3): 523-49.

Garzón, Eduardo. 2014. „Contrarréplica a Arcarons, Raventós y Torrens sobre el artículo de renta básica”. La Marea. http://www.lamarea.com/2014/08/29/contrarreplicaarcarons-raventos-y-torrens-sobre-el-articulo-de-renta-basica/ (dostęp 5 sierpnia 2017 r.)

Gasparini, Leonardo, Francisco Haimovich i Sergio Oliveri. 2009. „Labor Informality Bias of Poverty-Alleviation Program in Argentina". Journal of Applied Economics 12(2): 181-205.

Jackson, William A. 1999. „Basic income and the right to work: a Keynesian approach”, Journal of Post-Keynesian Economics 21 (4): 639-662.

Kaboub, Fadhel. 2013. „The Low Cost of Full Employment in the United States”. W The Job Guarantee: Toward True Full Employment, red. Michael J. Murray, Mathew Forstater. Basingstoke, New York: Palgrave Macmillan.

Lo Vuolo, Rubén M. 2004. „Las perspectativas del ingreso ciudadano frente a otras políticas en America Latina”, wystąpienie na X Kongresie BIEN, Barcelona, 18-21 września. http://www.basicincome.org/bien/pdf/2004Lo\%20Vuolo.pdf (dostęp 30 lipca 2017 r.)

Manjarin, Edgar i Maciej Szlinder. 2016. „A Marxist Argumentative Scheme on Basic Income and Wage Share in an Anti-Capitalist Agenda". Basic Income Studies 11(1): 1-11.

Mitchell, William i Martin Watts. 2005. „A Comparison of the Macroeconomic Consequences of Basic Income and Job Guarantee Schemes”. Rutgers Journal of Law \& Urban Policy 2(1): 64-90.

Moll, Łukasz. 2014 . „Bezwarunkowy dochód podstawowy w perspektywie ekospołecznej”. Praktyka Teoretyczna 2(12): 5976. 
Murray, Michael J. 2013. „Effective Demand, Technological Change, and the Job Guarantee Program". W The Job Guarantee: Toward True Full Employment, red. Michael J. Murray, Mathew Forstater. Basingstoke, New York: Palgrave Macmillan.

Standing, Guy. 2013. „Why a Basic Income Is Necessary for a Right to Work”. Basic Income Studies 7(2): 19-40.

Standing, Guy. 2017. „Alternatywy dla dochodu podstawowego: przegląd krytyczny”. Praktyka Teoretyczna 2 (24): 15-38.

Stockhammer, Engelbert. 2012. „Why Have Wage Shares Fallen? A Panel Analysis of the Determinants of Functional Income Distribution". Geneva: International Labour Office, Conditions of Work and Employment Branch.

Szlinder, Maciej. 2013. „Dochód podstawowy z perspektywy ekonomii politycznej Michała Kaleckiego". Nowa Krytyka 30/31: 87-106.

Szlinder, Maciej. 2016. „Wzrost czy post-wzrost? Potencjalne konsekwencje dochodu podstawowego". W Perfumy. Posłowie do dęindustrializacji, red. Mikołaj Iwański. Szczecin: Wydawnictwo Naukowe Akademii Sztuki w Szczecinie.

Tcherneva, Pavlina R. 2003. „Job or Income Guarantee.” Working Paper 29, Center for Full Employment and Price Stability, Kansas City, MO. http://www.cfeps.org/pubs/wppdf/WP29-Tcherneva.pdf

Tcherneva, Pavlina R. 2006. „Universal assurances in the public interest: Evaluating the economic viability of basic income and job guarantees". International Journal of Environment, Workplace, and Employment 2(1): 69-88.

Tcherneva, Pavlina R. 2013. „The Job Guarantee: Delivering the Benefits That Basic Income Only Promises - A Response to Guy Standing". Basic Income Studies 7(2): 66-87.

Tcherneva, Pavlina R. 2017. „Jakie są względne zalety makroekonomiczne i wpływ na środowisko płynące $z$ bezpośredniego tworzenia miejsc pracy oraz dochodu podstawowego?”. Praktyka Teoretyczna 2 (24): 125-154.

Torrens, Lluis. 2016. „Dochód podstawowy, wzrost gospodarczy i miasto”. Wywiad przeprowadzony przez Macieja Szlindera. Praktyka Teoretyczna. tłum. Maciej Szlinder. kwiecień. http://www.praktykateoretyczna.pl/dochod-podstawowywzrostgospodarczy-i-miasto/.

Widerquist, Karl i Allan Sheahan. 2012. „The United States: The Basic Income Guarantee Past Experience, Current Proposals". W Basic Income Worldwide: Horizons of Reform, red. Matthew C. Murray i Carole Pateman. New York \& Basingstoke: Palgrave Macmillan.

Wray, L. Randall L. 2013. „The Euro Crisis and the Job Guarantee: A Proposal for Ireland”. W The Job Guarantee: Toward True Full Employment, red. Michael J. Murray, Mathew Forstater. Basingstoke, New York: Palgrave Macmillan. 
Maciej Szlinder - doktor nauk humanistycznych w zakresie filozofii; socjolog, ekonomista. Redaktor „Praktyki Teoretycznej”. Publikował m. in. w „Basic Income Studies”, „Nowej Krytyce”, „Filo-Sofiji” i „Przeglądzie Ekonomicznym”. Tłumacz. Prezes Polskiej Sieci Dochodu Podstawowego, członek sieci europejskiej (Unconditional Basic Income Europe) i hiszpańskiej (Red Renta Básica).

\section{DANE ADRESOWE:}

Redakcja „Praktyki Teoretycznej”

Instytut Filozofii

Uniwersytetu im. A. Mickiewicza

ul. Szamarzewskiego 89c

60-780 Poznań

E-MAIL: mszlinder@gmail.com

CYTOWANIE: Szlinder, Maciej. 2017. „Problemy z argumentacją zwolenników Nowoczesnej Teorii Pieniężnej przeciw dochodowi podstawowemu: Komentarz do tłumaczenia". Praktyka Teoretyczna 2(24): 155-164.

DOI: $10.14746 /$ prt.2017.2.6

AUTHOR: Maciej Szlinder

TITLE: Problems with Modern Monetary Theory Proponents' Argumentation Against Basic Income: A Commentary to the Translation 